\title{
Chapter 2 Religious Freedom and Anti-Discrimination in Europe and the US: Generally Applicable Laws and Possible Exceptions
}

\author{
Iain McLean and Scot Peterson
}

\section{Introduction}

The American legal scholar Douglas Laycock argues that the same-sex marriage debate has been an instance of the 'Puritan mistake'. (Laycock 2008) According to Laycock, the Puritans came to the United States to gain religious freedom, but once they had a theocracy in Massachusetts that was enough liberty for them: people of other Christian denominations and other faiths could go elsewhere if they wanted to be free. His example shows the difficulty in maintaining a level playing field among different, potentially conflicting interests. Religious truth is one, which the Puritans were unwilling to compromise; ideology and public policy can also be uncompromising in their consequences.

One of the central themes of this book is the difficulty of identifying what beliefs count as religious and which do not. Related to that question is one about which beliefs are sufficiently central to a given system to merit protection. In order to resolve religious exemption or religious accommodation questions, it is then necessary to determine whether the state's power should prevail over these religious interests. These questions are the focus of this chapter, in which we explain the similarities between the approaches used by courts in the United States and Europe, in the former case in the context of the First Amendment to the US Constitution, in the latter, according to the European Convention on Human Rights, incorporated in the United Kingdom into the Human Rights Act 1998, c. 42. 
These are live questions, not just theoretical ones. As we write, the states of Indiana and Arkansas in the United States have been forced to modify statutes that would have given religious groups that object to same-sex marriage more powerful protections. ${ }^{1}$ Under pressure from business and other lobbyists, who believed that the statutes were a license to discriminate, the states changed the law, strengthening protections for lesbian, gay, bisexual and transgender (LGBT) people. (Davey and Goodstein, 2015) In the UK in 2007, Lilliane Ladele complained that her freedom of religion had been infringed by her employer, the London Borough of Islington, when she was required to participate in civil partnership ceremonies for same-sex couples, contrary to her religious beliefs. The case was finally resolved against her in 2013 by the European Court of Human Rights. (Eweida 2013)

The subject of same-sex marriage is the subject of chapter 13 of this book, and we have written about it elsewhere. (Peterson and McLean 2013) Our purpose in this chapter is to explore more general principles concerning the tension between law and religion, focusing particularly on religious exemptions from generally applicable laws. Nevertheless, we must recognize that the catalysts for these issues' recent salience have been LGBT rights in general and the move toward same-sex marriage in particular. In addition, we distinguish between two notions of churchstate interaction: secularity and secularism. (McLean and Peterson, 2011a; Scharffs, 2011)

Secularity is the noun corresponding to the adjective secular; secularism corresponds to secularist. For us, the second pair, secularism/secularist, coincides with ideological opposition to religion, particularly in the public square, and to religious justifications for individual action. This general opposition to public religion is most evident in radical forms of the French doctrine of laïcité and in policies like 
banning women from wearing the burqa. The first pair, secularity/secular, is ideologically neutral between religions and between religion and non-religion and implies separation between government and religion without suppressing public religious expression by individuals. The second model is applicable in the United States. In what follows we develop this distinction in the context of cases relating to religious exemptions from general laws. Our point here, in common with all contributors to this volume, is that 'religion or belief' should be treated equally before the law: no religion should be permitted to make rules that bind those who are not its followers. Nevertheless, we are not secularist: we do not wish to see religion, or religious arguments, barred from the public square.

\section{Abstract Principles for Deciding Concrete Cases}

In the United States between 1963 and 1990 requests for religious exemptions from general laws were examined by federal courts under the so-called 'strict scrutiny' test. $^{2}$ Although the actual influence of this test is contested, even sceptics concede that its zenith is Yoder (1972), a case which permitted Amish parents to withdraw their children from school after the eighth grade but before they had reached the statutory age of 16 . These parents believed that secondary education impermissibly exposes children to worldly influence, in conflict with their religious beliefs, because it emphasizes scientific accomplishments, self-distinction, competitiveness, worldly success, and social life with other students. They did not object to their children learning to read, write and perform arithmetic, as these enabled them to read the Bible, to be good farmers and citizens and to deal with non-Amish people that they came into contact with in daily life. However, everyone agreed that this basic level of education had been reached by the eighth grade. 
The U.S. Supreme Court found that compulsory education imposed by the state in these cases would 'gravely endanger if not destroy the free exercise of the [parents'] religious beliefs'. (Yoder 1972: 219) It then went on to consider both 'the interests that the State seeks to promote' by its education requirement, and 'the impediment to those objectives that would flow from recognizing the claimed Amish exemption'. (Yoder 1972: 221) In short, the court asked, how important is the state's interest in mandating a high school education for all students; and how detrimental to that interest is it to permit an exemption in this particular case? The court found that the goal of education was to prepare children for life; that learning-by-doing in the Amish community accomplished this objective as well as the theoretical education offered in public high schools; and that allowing an exemption was not sufficiently harmful to require a no-exception rule.

The framework of this analysis is what is critical. First, the court evaluated the harm done to the believer; it went on to address the importance of the state objective and the need to impose the harm, in order to accomplish the objective. It found that the harm outweighed the need to impose it and required that religious believers be afforded an exemption from the law. The initial, religious justification by the parents simply asserts a religious interest. That was enough to trigger a delicate balancing of interests, which weighed the harms at the margin of each side's concern. (Lupu, forthcoming 2015) A process like this is consistent with secularity, but not with secularism. For a secularist, taking the Amish parents' beliefs into account is an illegitimate move, because religious justifications for state action (or inaction) are disallowed. A secular state, however, adopts a neutral stance toward religion and can adapt the means it uses to accomplish its purposes (here education) to accommodate religious believers when necessary. We are not committed to the 
position that the court was correct in this case; what we want to emphasize is the process that it engaged in - the result could come out either way, depending on (1) the harm to the believer; (2) the importance of the state's objective; and (3) whether the harm is necessary to achieve the objective.

Similar questions are encountered under the European Convention on Human Rights, Article 9 of which provides,

1. Everyone has the right to freedom of thought, conscience and religion; this right includes freedom to change his religion or belief and freedom, either alone or in community with others and in public or private, to manifest his religion or belief, in worship, teaching, practice and observance.

2. Freedom to manifest one's religion or beliefs shall be subject only to such limitations as are prescribed by law and are necessary in a democratic society in the interests of public safety, for the protection of public order, health or morals, or for the protection of the rights and freedoms of others.

Section one defines the right to freedom of religion, including the rights to freedom of thought and conscience, which are unlimited; section two defines the limits on freedom to manifest one's religion: the limits must be necessary in a democratic society to protect (1) public order, health or morals; or (2) the rights and freedoms of others. In the first qualification, public order and health are both what economists call public goods, which must be provided by government (or else they will be undersupplied or not supplied at all); ${ }^{3}$ the second qualification is connected to negative externalities: adverse consequences to third parties from engaging in religious practice. Both are strong justifications for denying religious exemptions 
under the US constitution as well as the European Convention on Human Rights. (McConnell and Posner, 1989)

The case Jakóbski (2010) shows the European Court of Human Rights engaging in a similar kind of analysis to the Yoder case, above. In Jakóbski the applicant was a prison inmate who subscribed to the Buddhist religion and requested a vegetarian diet. First, the court found that a religious diet was a manifestation of belief protected by Article 9; it then went on to balance the financial and technical difficulties involved in providing a vegetarian diet to one inmate in a prison housing nearly 1,200 people. (Jakóbski 2010: \ 41, 51) It found that the meals did not have to be prepared, cooked or served in a particular way; they simply had to be free of meat. Accordingly, the court was 'not persuaded that the provision of a vegetarian diet to the applicant would have entailed any disruption to the management of the prison or to any reduction in the quality of meals served to other prisoners'. (Jakóbski 2010: ๆ 52) Although the court did not use the exact words, disruption to prison management would have fallen into the first category (public order), above-a public good; and a decline in others' food standards would have amounted to a negative externality: an infringement of the rights and freedoms of others.

\section{Statutory Exemptions}

Both the United States and the United Kingdom (and its predecessor states) have a long tradition of offering religious protection through statutory exemptions in legislation. One of the earliest of these is Lord Hardwicke's Marriage Act, ${ }^{4}$ which imposed rigorous requirements on couples who wished to marry, including parental consent if they were under 21 , public reading of banns, and a ceremony in the Church of England (Roman Catholic and other non-Anglican ceremonies were 
deemed invalid). (Outhwaite, 1995; Probert, 2009) However, exemptions were offered for Jews and Quakers, who were permitted to marry on their own premises and to maintain their own marriage records. This allowed some measure of religious freedom for these groups and avoided the conflicts that had arisen, for example, over Quaker refusals to pay tithes to Church of England clergy in the previous century. (Taylor, 1985)

A more modern instance of this kind of exemption was included in the Abortion Act 1967 (c. 87), section 4(1) of which says, '[N]o person shall be under any duty, whether by contract or by any statutory or other legal requirement, to participate in any treatment authorised by this Act to which he has a conscientious objection'. In Greater Glasgow Health Board (2014), ${ }^{5}$ two nurses objected to the expansion of their duties to include delegating, supervising and/or supporting staff who were providing care in connection with abortions. (Greater Glasgow Health Board 2014: I 19) In the Supreme Court, Lady Hale pointed out (obiter) that the purpose of the statute was to provide safe abortions, correcting the previous, uncertain state of the law. She also wrote that the conscience clause provision was a quid pro quo, which made it politically possible to accomplish this purpose. (Greater Glasgow Health Board 2014: ๆ 27) The nurses' duties, according to the UK Supreme Court, were not sufficiently closely related to the 'treatment' covered by the Abortion Act for them to invoke the conscience clause in section 4. As it happened, the UK court did not need to consider the religious character of the nurses' objections for procedural reasons. More general principles of employment discrimination law were left for the employment tribunal. (Greater Glasgow Health Board 2014: I 24) However, the clear purpose of the statutory exemption was to accommodate objections of the kind raised by the nurses in the case. 
The Abortion Act is relatively unusual in English law, which generally exempts religious organizations, rather than individuals, particularly in the area of discrimination law. (Sandberg and Doe, 2007) Sex discrimination has long been permitted when it allows an organized religion to comply with its own religious doctrine or to avoid conflict with its followers. ${ }^{6}$ From the first prohibitions of discrimination based upon sexual orientation, an exception has been made for religious organizations. ${ }^{7}$ Special provisions like these for religious groups have generally resulted from lobbying efforts by the religious groups themselves. (Cumper, 2000) However, they offer broad opt-outs from generally applicable law, without the need to show individual harm, as in Yoder. Religious organizations have also sometimes been able to require employees to be of a particular religion or belief, so long as that requirement is a proportionate means of achieving a legitimate aim, as in Yoder and Jakóbski. ${ }^{8}$

Individualized exemptions have been more common in statutes in the United States. ${ }^{9}$ Employment anti-discrimination law there allows religious discrimination when it is a bona fide occupational qualification, including in a non-religious context. An airline may require that all pilots who fly to Mecca be Muslims, since under Saudi law non-Muslims who go to Mecca are executed. (Kern 1983) Employers must also offer reasonable accommodation for religious requirements on a case-by-case basis.

Compared to the more narrowly tailored exemption rules discussed in the previous section, categorical statutory exemptions (like the ones for religious organizations) are somewhat less susceptible to judicial discretion, influencing whether protections are afforded. Rather than a broad, balancing test, which weighs religious (and other belief-related) interests against state power, these carve-outs may offer clearer protections to agreed groups or to religion generally on a 
particularly controversial policy. Their outcome is more certain, but they require that both sides of the negotiation have power and political support. Thus, they are less well-suited to protect minority rights than more individualized protections described in the previous section and in other kinds of statutes.

Law in the United States has moved in the direction of statutory exemptions and away from ones based on the First Amendment. One simple reason for this is that statutes are easier to change than judicially imposed rules about the meaning of the US Constitution. The Religious Freedom Restoration Act (RFRA) requires courts to engage in an analysis like the one used in Yoder when a federal law is being applied and a religious believer objects. ${ }^{10}$ At the time of writing, 21 states in the US have enacted so-called mini-RFRAs, which require state courts to do the same. ${ }^{11}$

None of these laws guarantees that the religious objector will win. Instead, they impose a particular method of reasoning, similar to the one used in Yoder and by the European Court of Human Rights. By diffusing these decisions to the state level in the US through mini-RFRAs, local judiciaries can be responsive to localized cultures and histories and can interpret mini-RFRAs in different ways depending on the circumstances their states. The European version of this federalization of law is the so-called margin of appreciation, which defers to the laws of individual member states, provided that they meet minimum thresholds imposed by the European Convention on Human Rights, just as all US states must meet the basic requirements imposed by the First Amendment.

The potential danger of these statutory solutions, when they are categorical ones negotiated by powerful groups, is that they will favour one group over another. In 2010 the Labour government sought to amend the requirements for religiously based employment (e.g. requiring that Roman Catholic priests be unmarried men), 
so that they were proportional, as well as consistent with the doctrines of a given religion. (McLean and Peterson, 2011b) A coalition of powerful religious groups, including the Church of England and the Roman Catholic Church broadened the religious exemption, with the Church of England's bishops in the House of Lords voting in the majority to defeat the government. ${ }^{12}$ Power politics of this kind forms a foundation for ad hoc exemption language that allows broad loopholes, to avoid conflict with doctrine or with 'the strongly held religious convictions of a significant number of the religion's followers'. ${ }^{13}$

Up to this point, it has been our purpose to describe less controversial areas where religious believers may be afforded exemptions from generally applicable laws. These exemptions arise in a variety of circumstances, including education and prisons, marriage law and health care. Examples could be multiplied further if space permitted, to include conscientious objections to military service (Bayatyan 2011), and even use of the internet to pay taxes. (Exmoor Coast 2014; Blackburn 2013) We now move on to the more topical and controversial question of the interaction between these frameworks and anti-discrimination laws that protect LGBT people and same-sex couples.

\section{Religious Freedom and Anti-Discrimination: the LGBT case}

Brett Scharffs (2011: 121-124) extends the distinction between secularist and secular using an argument advanced by Robert Cover (1983). In his Harvard Law Review article Nomos and Narrative, Cover develops the notion that communities create normative meanings, which can become sufficiently diverse that they cease to provide rules of conduct. Law-makers, broadly interpreted to include legislatures as well as courts, limit that diversity, allowing some meanings but disallowing others. 
Thin, liberal conceptions of the good can help law-makers narrow meanings, while also permitting a wide margin for alternative meanings and allowing for pluralism. But, according to Scharffs, an overly thick, secularist, notion of the good, which disallows religious meanings, can unnecessarily restrict alternative conceptions of the good that might be beneficial, as for example Christian conceptions of the good were useful in the fight for racial equality in the US in the 1960s. (Carter, 1994) This distinction helps to show why the cases that follow are important.

In September 2008 Steven Preddy telephoned Chymorvah House, a hotel in Marazion, Cornwall, to make a reservation for a room with a double bed for himself and his same-sex civil partner, Martyn Hall. Because of various circumstances, he was not told (as people normally were) that the owners of the hotel had a policy of only allowing rooms with double beds to married couples. When Preddy and Hall arrived, their reservation was not honoured. In 2013 the UK Supreme Court decided that the hotel owners, Peter and Hazelmary Bull, had violated UK equality law by refusing to rent Preddy and Hall a double room and allowed a damage award of $£ 1,800 .{ }^{14}$ (Bull 2013)

The five justices that decided the case disagreed over whether there had been 'direct' or 'indirect' discrimination, but that distinction is unimportant here. In their judgments they agreed that the discrimination could not be justified using an analysis akin to the one in Yoder and Jakóbski. Addressing the question of indirect discrimination, Lady Hale wrote, 'A fair balance should be struck between [the Bulls'] right to manifest their faith and the right of Mr Preddy and Mr [Hall] to obtain goods, facilities and services without discrimination on grounds of their sexual orientation.' ( (I4) She relied upon the fact that the legislature had created civil partnerships 'to encourage stable, committed, long-term relationships'. (\$ 36) Because civil 
partnerships have the same legal status as marriage, it was incumbent on all service providers to treat it in the same way as marriage in all cases. In her analysis of Article 9, Lady Hale found that the legitimate aim pursued by the legislature was protection of the rights and freedoms of Mr Preddy and Mr Hall, and no exemption was warranted.

Does this mean that the general legislation will always prevail over religious objections? It does not. Lady Hale also wrote that she was 'more than ready' to accept that a reasonable accommodation of religion might be part of the proportionality assessment in some cases, although it is difficult to know just which ones. Specifically, Lady Hale wrote that it would be difficult to convince her that offering a room with twin beds was a sufficient accommodation; however, an alternative approach she did not consider would be to ask whether the Bulls might have an arrangement with another hotel nearby, which offered equivalent services, so that they could generally refer same-sex couples to other accommodation with minimal trouble to anyone involved. An approach like this minimizes the economic costs to both parties, but it does not address the dignitary harm to the same-sex couple, who may feel stigmatized. Moreover, we can see that it harkens back to the days of other invidious prejudices, which were reinforced by signs notifying minorities that accommodation was not available to certain racial and ethnic groups and nationalities. This may be the source of Lady Hale's difficulty.

Another approach reduces the court's reasoning to its commercial context. (Giles, 2014) It seems possible that this might be a line Lady Hale would draw, when she distinguished between cases where accommodation might or might not be available. The United States Supreme Court has hinted in the past that the forprofit/non-profit distinction might be one that mattered for religious exemption 
purposes, although that has recently been abandoned, at least for purposes of RFRA. ${ }^{15}$ However, allowing for the possibility of non-profit (but not for-profit) exemptions from general laws when the general laws conflict with their religious purpose would allow additional room to accommodate Scharffs' concerns, summarized above.

A different approach has been taken in legislation recently passed by the State of Utah to protect LGBT people from discrimination. Senate Bill 296, signed into law 12 March 2015, offers the first protection of LGBT rights in a state dominated by Republican politicians, who hold majorities in both houses of the legislature as well as the governor's office, and where the influence of the Church of Jesus Christ of Latter-day Saints (Mormons), which opposes same-sex marriage, is particularly strong. The trigger for passage of this act was the legalization of samesex marriage in Utah through the decision of a federal court. (Kitchen 2013) Mormon leaders supported a bill that offered broad protections to LGBT people in employment and housing, while at the same time exempting religious societies and religious educational institutions. ${ }^{16}$ The law does not address discrimination in broader areas of commercial activity, such as the provision of goods and services (like wedding cakes and photographs, which present their own practical, political problems).

The law is a limited political compromise, which offers benefits to both sides in a continuing political struggle and leaves important questions (goods and services) unanswered. Like the exemption in the UK's abortion act, it corrects an existing injustice (unregulated prejudice against LGBT people) by incorporating an accommodation for religious institutions, including the Mormon-affiliated Brigham Young University. And, like other statutory exemptions, it was the product of 
negotiation between relatively powerful groups. But the solution is more than LGBT people in Utah could have expected, given the religious and political environment in the state.

Solutions like this can be traced back to some of the early state legislation that legalized same-sex marriage, while at the same time allowing generous exemptions for religious organizations. For example, New York's same-sex marriage law allows non-profit religious organizations to refuse to provide 'services, accommodations, advantages, facilities, goods, or privileges' for the solemnization of same-sex marriages and permits religious organizations to sell or rent housing in accordance with their religious doctrines. ${ }^{17}$

These are broad exemptions, but they were not discussed widely at the time that the New York law passed, because proponents of same-sex marriage wanted to emphasize that it was the most populous state to allow same-sex marriage at the time (2011); not the cost it incurred in doing so. Widespread popular support for same-sex marriage by progressives was balanced by powerful religious groups that demanded concessions as the price of allowing the legislation to pass. The same is true of the Utah bill, which is a way of building a normative structure that disallows discrimination against LGBT people in matters of employment and housing while protecting the ability of the Mormon Church and its affiliated institutions to withhold support for same-sex relationships.

\section{Conclusion}

We cannot present a clear, normative position on these questions, which remain highly contested and volatile. What we can do is to re-introduce some of the complexity that inheres in a difficult set of questions and which from an objective 
viewpoint resists clear answers, unless they are ideological ones. In an article authored before the Supreme Court decided the Bull case, one expert on law and religion in the UK argued that the regime here had moved from passive accommodation to prescriptive regulation. (Sandberg, 2011)

But Brett Scharffs' point remains. If general rules always prevail over the objections of religious believers, and particularly believers who advocate for unpopular, progressive political positions (e.g. against military conscription, more liberal marriage laws or racial desegregation, as in the United States in the 1960s), could there be a net loss overall? Judges are well-equipped to address logical arguments in support of policy-outliers like these, and they may also be wellequipped to make determinations about the limits of state power in areas where religious beliefs are implicated.

The framework that we have presented here, in which individual objections are weighed against state power and the harm incurred by exemptions (either by undermining a public good or by imposing negative externalities) presents one way of addressing this set of conflicts. Statutory exemptions, which may offer a different set of protections to a different class of believers, presents a different one. Neither dictates a particular outcome in any given case. Both offer useful ways of addressing religion and belief when they are burdened by civil law.

\section{References}

Carter S. (1994) The Culture of Disbelief. New York: Anchor Books.

Cover R. (1983) 'Forward: Nomos and Narrative'. Harvard Law Review 97:4-68.

Cumper P. (2000) 'Religious Organisations and the Human Rights Act 1998' in Edge $P$ and Harvey G (eds) Law and Religion in Contemporary Society. Aldershot: Ashgate. 
Davey M and Goodstein L. (2015) 'Religion Laws Quickly Fall Into Retreat in Indiana and Arkansas'. New York Times, available online at http://www.nytimes.com/2015/04/03/us/rights-laws-quickly-fall-into-retreat.html (last visited 4 April 2015).

Giles J. (2014) 'The Exercise of Religious Freedom in a Commercial Context: Preddy v Bull and other cases'. Oxford Journal of Law and Religion 3:512-517.

Laycock D. (2008) 'Afterword' in Laycock D, Picarello AR and Wilson RF (eds) Same-Sex Marriage and Religious Liberty: Emerging Conflicts. Lanham, Md.: Becket Fund for Religious Liberty, 189-207.

Lupu IC. (forthcoming 2015) 'Hobby Lobby and the Dubious Enterprise of Religious Exemptions'. Harvard Journal of Law and Gender.

McConnell MW and Posner RA. (1989) 'An Economic Approach to Issues of Religious Freedom'. University of Chicago Law Review 56:1-60.

McLean I and Peterson S. (2011a) 'Secularity and Secularism in the United Kingdom: On the Way to the First Amendment'. Brigham Young University Law Review, 637-656.

McLean I and Peterson S. (2011b) 'A Uniform British Establishment' in Chapman M, Maltby $\mathrm{J}$ and Whyte W The Established Church: Past, Present and Future, London: T\&T Clark, International.

Outhwaite RB. (1995) Clandestine Marriage in England, 1500-1850, London: Hambledon Press.

Peterson S and McLean I. (2013) Legally married : love and law in the UK and the US, Edinburgh: Edinburgh University Press.

Probert R. (2009) Marriage Law and Practice in the Long Eighteenth Century: A Reassessment, Cambridge: Cambridge University Press.

Sandberg R. (2011) 'The Right to Discriminate'. Ecclesiastical Law Journal 13:157181.

Sandberg R and Doe N. (2007) 'Religious Exemptions in Discrimination Law'. The Cambridge Law Journal 66:302-312.

Scharffs BG. (2011) 'Four Views of the Citadel: The Consequential Distinction between Secularity and Secularism'. Religion \& Human Rights 6:109-126.

Taylor S. (1985) 'Sir Robert Walpole, The Church of England, and the Quakers Tithe Bill of 1736'. The Historical Journal 28:51-77. 


\section{Cases Cited}

Bayatyan v. Armenia [2011] ECtHR App. No. 23459/03 (7 July 2011) [Byatyan 2011].

Blackburn \& Anor v. Revenue and Customs [2013] UKFTT 525 (TC) (2 October 2013) [Blackburn 2013].

Bull and Anor v. Hall and Anor [2013] UKSC 73 [Bull 2013].

Burwell v. Hobby Lobby Stores, Inc., 573 U.S. , 134 S.Ct. 2751 (2014) [Burwell 2014].

Cantwell v. Connecticut, 310 US 296 (1940) [Cantwell 1940].

Employment Division v. Smith, 494 U.S. 872 (1990) [Employment Division 1990].

Eweida \& Ors v United Kingdom [2013] ECtHR 37 No. 51671/10 [Eweida 2013].

Exmoor Coast Boat Cruises Ltd v. Revenue and Customs [2014] UKTT 1103 (TC) (17 December 2014) [Exmoor Coast 2014].

Gonzales v. O Centro Espirita Beneficente Uniao do Vegetal, 546 U.S. 418 (2006) [Gonzales 2006].

Greater Glasgow Health Board v. Doogan and Anor [2014] UKSC 68 [Greater Glasgow Health Board 2014].

Jakóbski v. Poland [2010] ECtHR App. No. 18429/06 (7 December 2010) [Jakóbski 2010].

Kern v. Dynalectron Corp., 577 F.Supp. 1196 (N.D. Tex. 1983) [Kern 1983].

Kitchen v. Herbert, 961 F.Supp. 2d 1181 (D. Utah 2013), aff'd 755 F.3d 1193 (10 ${ }^{\text {th }}$ Cir. 2014), cert. den. 2014 WL 3841263 (6 October 2014) [Kitchen 2013].

Sherbert v. Verner, 374 U.S. 398 (1963) [Sherbert 1963].

Tony \& Susan Alamo Foundation v. Sec'y of Labor, 471 U.S. 290 (1985) [Tony \& Susan Alamo Foundation 1985].

United States v. Lee, 455 U.S. 252, 261 (1982) [US v. Lee 1982].

Wisconsin v. Yoder, 406 U.S. 205 (1972) [Yoder 1972].

\section{Notes}

${ }^{1}$ State of Indiana, $119^{\text {th }}$ General Assembly, First Regular Session, Senate Enrolled Act No. 50, available online at https://iga.in.gov/documents/1bdf457b (last visited 17 April 2015); State of Indiana, $119^{\text {th }}$ General Assembly, First Regular Session, Senate Enrolled Act No. 101 , available at https://iga.in.gov/documents/92bab197 (last visited 17 April 2015); State of 
Arkansas, $90^{\text {th }}$ General Assembly, Regular Session 2015, Senate Bill 975 and amendments, available online at http://www.arkleg.state.ar.us/assembly/2015/2015R/Bills/SB975.pdf and http://www.arkleg.state.ar.us/assembly/2015/2015R/Amendments/sb975-S1.pdf (last visited 17 April 2015).

${ }^{2}$ The strict scrutiny test is a doctrine developed by the United States Supreme Court to articulate the principle of religious freedom in the First Amendment to the United States Constitution, which provides, 'Congress shall make no law respecting an establishment of religion or prohibiting the free exercise thereof ...' Since 1940 the amendment has also applied to state and local laws. (Cantwell 1940). The period begins with Sherbert (1963) and ends with Employment Division (1990), which strictly limited courts' use of the test we focus on here.

3 'Morality' does not fit comfortably with the other two, unless it is a very thin kind of morality closely related to public order and the rights and freedoms of others. The statutory canon noscitur a sociis might justify such an interpretation.

${ }^{4}$ An Act for the Better Prevention of Clandestine Marriage 1753, 26 Geo. 2 c. 33.

${ }^{5}$ Greater Glasgow Health Board (2014) reversing Doogan and Anor v. Greater Glasgow and Clyde Health Board [2013] CSIH 36, reversing [2012] CSOH 32. There are three legal jurisdictions in the UK: England \& Wales, Scotland, and Northern Ireland. Scots law is the most distinctive of the three, and has separate rules, procedures, and domains. For the differences in the area of marriage see Peterson and McLean (2013). Most domestic policy is devolved to the Scottish Parliament; however, abortion policy is not, and the 1967 Act covered Scotland. Doogan was decided by the UK Supreme Court, reversing a decision of the Inner House of the Court of Session in the nurses' favour, which had itself reversed a decision by the Outer House of the Court of Session, which is the court of first instance in that jurisdiction. 
${ }^{6}$ Sex Discrimination Act 1975 c. 65 § 19; Equality Act 2010 c. 15 Schedule 9 § 2.

${ }^{7}$ Equality Act 2006 c. 3 and the Equality Act (Sexual Orientation) Regulations 2007 No. 1263; Equality Act 2010, Schedule 9, § 2-3.

${ }^{8}$ See Equality Act 2010, Schedule 9 § 3.

${ }^{9}$ See, e.g., 42 U.S.C. $\S \S 2000$ e-1(a), 2000-2(e)(2) (religious employers can discriminate based upon religion).

1042 U.S.C. $\S \S 2000$ bb-2000bb-4; Gonzales (2006).

${ }^{11}$ Baptist Joint Committee for Religious Liberty, State RFRA Bill Tracker, online at http://bjconline.org/state-rfra-tracker-2015/ (last visited 4 April 2015).

12 HL Parl. Debs (series 6) vol. 716 cols $1212-1243$.

${ }^{13}$ Equality Act 2010, Schedule 9, § 2(5)-(6).

${ }^{14}$ The court applied the Equality Act 2006 and the Equality Act (Sexual Orientation) Regulations 2007, note 7 above.

${ }^{15}$ US v. Lee (1982) ('When followers of a particular sect enter into commercial activity as a matter of choice, the limits they accept on their own conduct as a matter of conscience and faith are not to be superimposed on the statutory schemes which are binding on others in that activity.') See also Tony \& Susan Alamo Foundation (1985). The court's recent decision in Burwell (2014) permits closely held, for-profit corporations to claim exemptions under RFRA.

${ }^{16}$ State of Utah, 2015 General Session, Senate Bill 296: Antidiscrimination and Religious Freedom Amendments, available online at http://le.utah.gov/ 2015/bills/static/SB0296.html (last visited 4 April 2015). 
The Social Equality of Religion or Belief

17 NY Domestic Relations Law, § 10-b. 